CASSOWARY volume 4 (2) Juni 2021: 139-148

ISSN : :2614-8900

E-ISSN : 2622-6545

Program Pascasarjana Universitas Papua, https://pasca.unipa.ac.id/

\title{
Kondisi sanitasi pada kapal kargo di Wilayah Kerja Kantor Kesehatan Pelabuhan (KKP) Kelas III Manokwari
}

\section{Syamsudin $^{1}$, Vera Sabariah ${ }^{1 * 2}$, Meike M. Lisangan ${ }^{1,3}$ Zita L Sarungallo $^{1}$, Hendri ${ }^{4}$, Yuanike Kaber ${ }^{1}$}

${ }^{1}$ Program Studi S2 Ilmu Lingkungan Program Pascasarjana, Universitas Papua, Jl.

Gunung Salju Amban, Manokwari, 98314, Papua Barat

${ }^{2}$ Fakultas Perikanan dan Ilmu Kelautan, Universitas Papua, Jl. Gunung Salju Amban,

Manokwari, 98314, Papua Barat

${ }^{3}$ Fakultas Teknologi Pertanian, Universitas Papua, Jl. Gunung Salju Amban, Manokwari, 98314, Papua Barat

${ }^{4}$ Program Studi S2 Ilmu Kehutanan, Program Pascasarjana, Universitas Papua, Jl.

Gunung Salju Amban, Manokwari, 98314, Papua Barat

*Email: v.sabariah@unipa.ac.id

\begin{abstract}
Ship sanitation and its environment are a mandate from International Health Regulation (IHR)2005 and the regulation of Ministry of Health Republic IndonesiaNo 40 Tahun 2015 that request all the ship in Indonesia territory should have a certificate of ship sanitation. This is due to prevent, protect and control spreading of diseases. This study aimed to analyze the sanitation condition of cargo ships in working area of Harbour Health Office (KKP) type III Manokwari. Research location was done in Manokwari Harbour on September to October 2020. Method used in this study was descriptive approach and direct observation. Sample was obtained by purposive sampling, that 13 (thirteen) cargo ships anchored in Manokwari. Variables observed included room sanitation, vector, foods and drinking water, and waste. Results showed that in general the sanitation of the 13 cargo ships was qualified good (91.21\%), except for warehouse and medical facilitation. There were two ships (15.38\%) unqualified because had no storage room for dry and wet foods. Moreover, six cargo ships (46.15\%) had no medical facilitation according to the requirement, but only some medicines without observation room and medical tools. On the other hands, the vector and disease-spread animals, management food and drinking water, as well as the waste management for 13 cargo ships were qualified.
\end{abstract}

Keywords: sanitation condition, cargo ship, Manokwari harbour

\section{PENDAHULUAN}

Sanitasi kapal merupakan suatu usaha yang ditujukan terhadap faktor risiko lingkungan di kapal untuk memutuskan mata rantai penularan penyakit guna memelihara dan mempertinggi derajat kesehatan. Sanitasi kapal mencakup seluruh aspek penilaian kompartemen kapal antara lain dapur, ruang penyediaan makanan, palka, gudang, 
kamar anak buah kapal, penyediaan air bersih, dan penyajian makanan serta pengendalian vektor penular penyakit atau rodent (WHO,2005). Putri $d k k$ (2017) melaporkan bahwa terdapat $14,5 \%$ kehadiran vektor dari 16 kapal kargo dan penumpang yang diamatinya di pelabuhan Tanjung Emas Semarang. Sofyan dan Keman (2017) mengemukakan adanya vektor penular penyakit pada 23 kapal dari 2734 kapal yang diperiksa pada tahun 2015 di wilayah Kantor Kesehatan Pelabuhan (KKP) Kelas I Surabaya.

Sanitasi kapal adalah amanat dari International Health Regulation (IHR) 2005 dengan tujuan dan ruang lingkup adalah untuk mencegah, melindungi dan mengendalikan terjadinya penyebaran penyakit secara international serta melaksanakan respon kesehatan masyarakat sesuai dengan risiko kesehatan masyarakat, dan menghindarkan hambatan yang tidak perlu terhadap perjalanan dan perdagangan internasional. Keputusan Menteri Kesehatan RI Nomor 431 Tahun 2007 juga mengamanatkan pentingnya sanitasi lingkungan dalam rangka upaya pencegahan penyebaran penyakit karantina dan penyakit menular potensial wabah dilakukan dengan mengusahakan agar wilayah pelabuhan dan alat angkut tidakmenjadi sumber penularan atau habitat bagi perkembangbiakan kuman atau vektor penyakit. Hal ini juga diperkuat dengan adanya Peraturan Menteri Kesehatan Republik Indonesia nomor 40 Tahun 2015 yang mengamanatkan kewajiban setiap kapal di wilayah perairan Indonesia untuk memiliki sertifikat Sanitasi Kapal, yakni diberikan kepada kapal yang telah dilakukan pemeriksaan sanitasi.

Pelabuhan Manokwari merupakan salah satu pelabuhan yang melayani pelayaran domestik. Jumlah kedatangan kapal kargo cenderung meningkat dari
$70 \mathrm{kapal} /$ tahun menjadi $637 \mathrm{kapal} / \mathrm{tahun}$ pada lima tahun terakhir ini, dikarenakan adanya keberadaan pabrik semen SDIC Manokwari. Tercatat pada tahun 2018-2019, dengan jumlah penerbitan SSCEC/SSCC sebanyak 352 sertifikat (KKP Manokwari, 2019). Keadaan ini menunjukan bahwa pemeriksaan sanitasi kapal menjadi agenda rutin dan tugas penting bagi KKP, sehingga kapal-kapal yang berlabuh di seluruh pelabuhan di Manokwari terjamin sanitasi kapalnya dan bebas dari sumber penularan penyakit khususnya penyakit yang berpotensiwabah. Kondisi sanitasi kapal kargo yang masuk di pelabuhan Manokwari belum banyak diinformasikan, padahal mobilitas orang dan barang semakin cepat dapat melebihi masainkubasipenyakitmenular jika ada. Oleh karenanya, penelitian ini bertujuan untuk menganalisis kondisi sanitasi kapal kargo di Wilayah Kerja Kantor Kesehatan Pelabuhan (KKP) Kelas III Manokwari.

\section{MATERI DAN METODE Waktu dan Tempat}

Penelitian ini dilaksanakan di di Wilayah Kerja Kantor Kesehatan Pelabuhan (KKP) Kelas III Manokwari, pada bulan September-Oktober 2020. Meskipun pada masa pandemi COVID19, pemeriksaan sanitasi kapal tetap dilaksanakan semestinya sebagai persyaratan yang harus dipenuhi oleh kapal untuk masuk ke pelabuhan Manokwari.

\footnotetext{
Alat dan Bahan

Bahan penelitian ini adalah 13 kapal kargo dalam negeri yang masuk di pelabuhan Manokwari. Alat yang digunakan adalah formulir pemeriksaan sanitasi kapal (International Health Regulation, 2005) yang dirincikan pada metode, serta kamera untuk dokumentasi.
} 


\section{Metode}

Penelitian ini berupa observasi dengan cara pendekatan deskriptif (Sofyan dan Keman, 2017), yang dilakukan dalam 4 tahap meliputi (a) observasi kondisi ruangan sanitasi kapal kargo, terdiri dari ruangan dapur,ruangan rakit makanan, gudang, ruangan tidur $\mathrm{ABK}$, deck, ruang mesin, (b) observasi keberadaan vektor pembawa penyakit, untuk memastikan ada/tidak keberadaan vektor seperti lalat, kecoa, tikus di dalam kapal (c) observasi pengelolaan makanan dan minuman, untuk memastikan bahwa makanan telah dilakukan pengolahan dan ketersediaan air bersih serta air minum di dalam kapal memenuhi syarat kesehatan; dan (d) observasi pengelolaan limbah di kapal.

Variabel pengamatan dalam penelitian ini dihitung sebagai berikut:

$$
\begin{gathered}
\text { Skor Sanitasi Ruangan }(A)=\frac{\text { Jumlah skor variabel ruangan } x \text { Bobot variabel ruangan }}{\text { Sub Total Variabel Ruangan }} \\
\text { Skor Vektor }(B)=\frac{\text { (Jumlah skor variabel vektor) } x \text { Bobot variabel vektor }}{\text { Sub Total Variabel Vektor }}
\end{gathered}
$$

\footnotetext{
Skor Makanan dan Minuman $(C)=\frac{\text { (Jumlah skor variabel makanan dan minuman)X Bobot variabel Makanan dan Minuman }}{\text { Sub Total variabel makanan dan minuman }}$

Skor Limbah (D) $=\frac{\text { (Jumlah skor variabel limbah) } x \text { Bobot variabel limbah }}{\text { Sub Total Variabel limbah }}$
}

\section{AnalisisData}

Data hasil pemeriksaan sanitasi kapal yang telah dikumpulkan kemudian diolah untuk penilaian. Apabila variabel memenuhi syarat maka akan diberikan nilai sesuai dengan sub bobot, dan jika variabel tidak memenuhi syarat maka akan diberikan nilai 0 (nol). Selanjutnya seluruh variabel akan dihitung dengan rumus:

Skor Ruangan(A): Total A/100x10

Skor Vektor(B): Total B/100 x 30

Skor Makanan dan Minuman (C): Total $\mathrm{C} / 100 \times 50$

Skor Limbah(D):Total D/100x10

Total variabel untuk mendapatkan total skor kapal, dengan rumus :

Total Skor Kapal: (Skor A+B+C+D)

Jika hasil akhir menunjukkan nilainya $\geq 90$ berarti sanitasi pada kapal dikatakan baik, dan sebaliknya apabila nilainya $<90$ maka sanitasi dikatakan buruk (IHR,2005).

\section{HASIL DAN PEMBAHASAN}

Pemeriksaan kapal terutama kapal kargo meliputi pemeriksaan sanitasi kapal, pemeriksaan dokumen kapal dan pemeriksaan kelengkapan P3K kapal. Pemeriksaan kapal kargo di masa pandemi COVID-19 dilakukan terhadap semua kapal yang datang dari daerah terjangkit sesuai dengan Kepmenkes nomor 425/Menkes/SK/IV/2007. Kapal tersebut diminta untuk menurunkan jangkar di laut wilayah berlabuh menunggu pemeriksaan lanjutan. Kecuali bagi kapal-kapal yang memuat sembako atau barang yang mudah membusuk dan harus segera bongkar muat, maka diijinkan untuk sandar di dermaga, setelah ada pemeriksaan dari pihak Kantor Kesehatan Pelabuhan (KKP). Pemeriksaan sanitasi kapal merupakan merupakan kewenangan KKP. KKP adalah unit pelaksanan 
teknis di Lingkungan Kesehatan Republik Indonesia yang berada di bawah dan bertanggungjawab kepada Direktorat Jenderal Pengendalian Penyakitdan Penyehatan Lingkungan (Ditjen-PPPL). Hasil pemeriksaan sanitasi kapal terbagi atas dua rekomendasi yaitu bebas tindakan sanitasi (SSCEC), dan dengan tindakan sanitasi (SSCC). Apabila kapal dinyatakan 'bebas Tindakan sanitasi', maka diterbitkan dokumen Ship Sanitation Control Exemption Certificate (SSCEC), namun apabila kapal dinyatakan 'dengan tindakan sanitasi', tindakan yang dilakukan adalah fumigasi dan desinfeksi untuk selanjutnya diterbitkan dokumen Ship Sanitation Control Certificate (SSCC).

\section{SanitasiRuangan Kapal}

Komponen penilaian sanitasi ruangan meliputi kondisi ruang dapur, ruang rakit makanan (pantry), ruang gudang, ruang tidur abk, geladak (deck), ruang mesin, dan fasilitas medik (Tabel $1)$.

Tabel 1. Sanitasi Ruangan KapalKargo di PelabuhanManokwari

\begin{tabular}{|c|c|c|c|}
\hline No & Sanitasi Ruangan & Jumlah & Persentase (\%) \\
\hline \multirow[t]{4}{*}{1} & Ruang Dapur & & \\
\hline & Memenuhi syarat & 13 & 100 \\
\hline & Tidak Memenuhi Syarat & 0 & 0 \\
\hline & Jumlah & 13 & 100 \\
\hline \multirow[t]{4}{*}{2} & Ruang rakit makanan (pantry) & & \\
\hline & Memenuhi syarat & 13 & 100 \\
\hline & Tidak Memenuhi Syarat & 0 & 0 \\
\hline & Jumlah & 13 & 100 \\
\hline \multirow[t]{4}{*}{3} & Ruang Gudang & & \\
\hline & Memenuhi syarat & 11 & 84.62 \\
\hline & Tidak Memenuhi Syarat & 2 & 15.38 \\
\hline & Jumlah & 13 & 100 \\
\hline \multirow[t]{4}{*}{4} & Ruang tidur $\mathrm{ABK}$ & & \\
\hline & Memenuhi syarat & 13 & 100 \\
\hline & Tidak Memenuhi Syarat & 0 & 0 \\
\hline & Jumlah & 13 & 100 \\
\hline \multirow[t]{4}{*}{5} & Geladak (deck), & & \\
\hline & Memenuhi syarat & 13 & 100 \\
\hline & Tidak Memenuhi Syarat & 0 & 0 \\
\hline & Jumlah & 13 & 100 \\
\hline \multirow[t]{4}{*}{6} & Ruang Mesin & & \\
\hline & Memenuhi syarat & 13 & 100 \\
\hline & Tidak Memenuhi Syarat & 0 & 0 \\
\hline & Jumlah & 13 & 100 \\
\hline \multirow[t]{4}{*}{7} & Fasilitas Medik & & \\
\hline & Memenuhi syarat & 7 & 53.85 \\
\hline & Tidak Memenuhi Syarat & 6 & 46.15 \\
\hline & Jumlah & 13 & 91.21 \\
\hline
\end{tabular}


CASSOWARY volume 4 (2) Juni 2021: 139-148

ISSN : 2614-8900

E-ISSN : 2622-6545

Program Pascasarjana Universitas Papua, https://pasca.unipa.ac.id/

Variabel sanitasi ruangan meliputi dapur, ruang rakit makanan, ruang mesin, ruang tidur $\mathrm{ABK}$ dan geladak memenuhi syarat. Dari 13 kapal yang diperiksa, terdapat dua kapal $(15.38 \%)$ tidak memenuhi syarat yaitu komponen gudang, karena tidak memiliki gudang penyimpanan bahan makanan kering dan basah. Komponen lain yang tidak memenuhi syarat adalah ketersediaan fasilitas medik yang lengkap sebanyak enam kapal (46.15\%), karena hanya tersedia obat-obatan saja tanpa adanya ruang pemeriksaan dan peralatan medis lainnya.

Kondisi sanitasi ruang dapur di seluruh kapal kargo yang diperiksa di pelabuhan Manokwari adalah bersih, tidak terlihat kotoran dan sampah dibuang pada tempatnya. Tersedia tempat sampah di area dapur. Pertukaran udara baik, asap dapur dibuang melalui cerobong asap/ exhauster/ventilasi biasa. Pencahayaan baik untuk memasak. Sarana pencucian pada seluruh kapal yang diperiksa memenuhi syarat. Tersedian air yang cukup dan air mengalir denganlancar. Putri $d k k$ (2017) menyatakan dapur yang bersih adalah tidak tampak kotoran, tertata rapi, dan sampah dibuang pada tempatnya. Pertukaran udara dapur yang baik adalah asap dapur dibuang melalui cerobong asap, exhauster, atau ventilasi biasa. Sedangkan pada sub variabel pencahayaan dikategorikan baik jika dapat digunakan untuk membaca koran dengan nyaman. Ruang dapur yang memenuhi syarat menjadi aman dalam menjaga kualitas makanan saat diolah sehingga bahan makanan dan makanan terbebas dari kontaminasi bahan pencemar dan vektor. Dapur di kapal kargo merupakan tempat yang paling penting dan krusial dalam proses pengolahan makanan dapat memungkinkan terjadinya penyebaran penyakit atau kontaminasi melalui vektor dan makanan (Humaan, 2012).

Sanitasi ruang rakit makanan(pantry) dari kapal kargo dalam keadaan yang bersih, tertata rapi, dan pantry selalu dibersihkan setiap selesai tahap penyajian makanan. Ruang pantry yang memenuhi syarat menjadi aman dalam menjaga kualitas makanan, karena dapat menghindarkan makanan dari kontaminasi bahan pencemar dan vektor. Sofyan dan Keman (2017) mengemukakan bahwa penyimpanan makanan yang baik, dapat meminimalkan terjadinya kontaminasi, terlindung dari serangga dan binatang pengganggu serta penurunan mutu makanan. Sumantri (2010) menyatakan penyajian makanan yang telah matang harus memenuhi persyaratan sanitasi yaitu bebas dari kontaminasidan bersih, dapat memenuhi selera makan.

Ruang mesin, ruang tidur $\mathrm{ABK}$ dan geladak memenuhi syarat sesuai dengan persyaratan yang tercantum dalam Handbook for inspection of ships and issuance of ship sanitation certificates. Setiap ruangtidur $\mathrm{ABK}$ dalam kondisi bersih, pertukaran udara baik dengan menggunakan $\mathrm{AC}$, dan pencahayaan cukup. Demikian juga dengan ruang geladak dan ruang mesin pada 13 kapal kargo yang diperiksa, telah memenuhi syarat. Geladak (deck) dalam keadaan bersih, tidak terlihat kotoran dan tersedia tempat sampah, pertukaran udara baik. Menurut Sofyan dan Keman (2017), pertukaran udara dan penerangan yang cukup serta kebersihan dapat menjamin kesehatan, kesejahteraan serta keamanan $\mathrm{ABK}$ maupun penumpang. Bila penerangan secara alami tidak mencukupi, maka diberikan penerangan secara mekanis dengan menggunakan lampu neon. Ruang mesin yang ada pada semua kapal kargo yang diperiksa dalam keadaan bersih, tidak terdapat 
sampah yang berserakan, serta pencahayaan baik. Pada seluruh kapal yang diperiksa tidak ditemukan vektor ataupun tanda-tanda kehidupan vektor. Ruang mesin yang memenuhi syarat terutama dalam hal pencahayaan, menjadi aman bagi petugas di ruang mesin dalam memantau dan memeriksa keadaan mesin. Selain itu pertukaran udara yang baik juga dapat mencegah terjadinya ketidaknyamanan akibat kondisi panas dari mesin (Siregar, 2019) .

Terdapat dua kapal yang tidak memenuhi syarat sanitasi gudang. Kapal tersebut tidak memiliki fasilitas gudang penyimpanan bahan makanan kering dan basah. Bahan makanan kering disimpan di kulkas dan sisanya di simpan di wadah dan diletakkan di meja, seperti bawang merah dan bawang putih. Bahan makanan basah seperti ikan dan daging juga disimpan didalam kulkas atau tempat khusus bahan makanan kering. Bahan makanan di lemari harus diatur dengan baik dan rapi (Marpaung dkk, 2012). Menurut Suryani (2020), ruang penyimpanan bahan makanan dibagi dua yaitu (a) penyimpanan perkakas dan makanan yang kering atau tidak mudahbusuk, dan (b) penyimpanan berpendingin untuk makanan yang mudah busuk.

Hasil observasi kapal kargo yang tidak memiliki fasilitas medic lengkap sebanyak 6 kapal (46.15\%). Di kapal tersebut hanya tersedia obat-obatan saja tanpa adanya ruang pemeriksaan dan peralatan medis lainnya. Hal ini tidak sesuai dengan persyaratan yang tercantum dalam Handbook for inspection of ships and issuance of ship sanitation certificates. WHO (2011) menganjurkan semua kapal untuk memiliki lemari obat, peralatan medis dan panduan medis. Namun jumlah standar jenis obat dan peralatan medis dengan mempertimbangkan jenis kapal, jumlah orang di kapal, tujuan dan lamanya perjalanan di atas kapal.

\section{Keberadaan vector pembawa penyakit}

Keberadaan vektor dan binatang penular penyakit di kapal kargo yang diperiksa tidak ditemukan, menandakan bahwa kondisi kapal terawat baik. Selain itu, diamati ada terpasangnya ratguard pada setiap tali kapal kargo yang diperiksa.

Tabel 2. Vektor dan binatang penular penyakit Kapal Kargo di Pelabuhan Manokwari

\begin{tabular}{|c|c|c|c|}
\hline No & Vektor dan binatang penular penyakit & Jumlah & $\begin{array}{c}\text { Persentase } \\
(\%)\end{array}$ \\
\hline \multirow[t]{4}{*}{1} & $\begin{array}{l}\text { Tidak diitemukan vektor dan bianatang } \\
\text { pembawa penyakit }\end{array}$ & & \\
\hline & Memenuhi syarat & 13 & 100 \\
\hline & Tidak Memenuhi Syarat & 0 & 0 \\
\hline & Jumlah & 13 & 100 \\
\hline \multirow[t]{4}{*}{2} & $\begin{array}{l}\text { Terpasang rat guard pada setiap tali } \\
\text { kapal yang bersandar }\end{array}$ & & \\
\hline & Memenuhi syarat & 13 & 100 \\
\hline & Tidak Memenuhi Syarat & 0 & 0 \\
\hline & Jumlah & 13 & 100 \\
\hline
\end{tabular}


Kapal kargo yang diperiksa tidak diketemukan vektor pembawa penyakit di dalam kapal, baik tikus, nyamuk, kecoa maupun lalat. Keberadaan vektor di dalam alat angkut dapat mengakibatkan Public Health Emergency Of International Concern (PHEIC). PHEIC adalah suatu kejadian luar biasa yang dapat menjadi ancaman kesehatan bagi negara lain. Penyakit-penyakit yang berpotensi sebagai PHEIC jika ditemukan vektor pembawa penyakit antara lain pes dan demam lassa yang disebabkan oleh vektor tikus, penyakit yellow fever, west nile fever dan demam berdarah dengue (DBD).

\section{Pengelolaan makanan danminuman}

Komponen penilaian pengelolaan makanan dan minuman dalam pemeriksaan sanitasi kapal kargo di pelabuhan Manokwari meliputi pengelolaan makanan, penyediaan air minum dan air bersih.

Pengelolaan maupun pengolahan makanan pada kapal kargo dilakukan dari mulai tahap pemilihan bahan makanan hingga penyajian makanan.
Penjamah makanan pada semua kapal kargo yang diinspeksi dalam kondisi sehat, namun tidak menggunakan baju yang khusus digunakan hanya pada saat mengolah makanan, tidak menggunakan sarung tangan, ataupun pelindung kepala. Siregar (2019) menyatakan penggunaan baju yang bersih dan sarung tangan dapat mengurangi potensi risiko terjadinya kontaminasi makanan yang berasal dari rambut dan kuman ataupun toksin yang terdapat pada tangan maupun pada baju yang digunakan penjamah makanan. Sangat dianjurkan menggunakan baju bersih yang khusus digunakan pada saat mengolah makanan, menggunakan sarung tangan, dan penutup kepala untuk mencegah terkontaminasinya makanan yang dapat berasal dari rambut dan bakteri yang ada di tangan para penjamah makanan.

Penyediaan air minum di kapal kargo memenuhi syarat kesehatan, sesuai dengan persyaratan Handbook for inspection of ships and issuance of shipsanitation certificates.

Tabel 3. Pengelolaan Makanan dan Minuman pada Kapal Kargo di Pelabuhan

\begin{tabular}{|c|c|c|c|}
\hline No & $\begin{array}{c}\text { Pengelolaan makanan dan } \\
\text { minuman }\end{array}$ & Jumlah & $\begin{array}{l}\text { Persentase } \\
(\%)\end{array}$ \\
\hline \multirow[t]{4}{*}{1} & Makanan & & \\
\hline & Memenuhi syarat & 13 & 100 \\
\hline & Tidak Memenuhi Syarat & 0 & 0 \\
\hline & Jumlah & 13 & 100 \\
\hline \multirow[t]{4}{*}{2} & Air Minum & & \\
\hline & Memenuhi syarat & 13 & 100 \\
\hline & Tidak Memenuhi Syarat & 0 & 0 \\
\hline & Jumlah & 13 & 100 \\
\hline \multirow[t]{4}{*}{3} & Air Bersih & & \\
\hline & Memenuhi syarat & 13 & 100 \\
\hline & Tidak Memenuhi Syarat & 0 & 0 \\
\hline & Jumlah & 13 & 100 \\
\hline
\end{tabular}


Penyediaan air minum tidak hanya sebatas pada kualitas air minum yang akan dikonsumsi, namun juga tersedianya air minum dalam jumlah yang cukup. Air minum yang dikonsumsi di kapal bersumber dari air galon. Hasil pengukuran kualitas air minum baik secara fisik dengan parameter Total Disolved Solid (TDS) pada kisaran $500 \mathrm{mg} /$ liter dan $\mathrm{pH}$ 6,58,5untuk sampel air masih memenuhi syarat kesehatan sesuai Peraturan Menteri Kesehatan Republik Indonesia No. 492 tahun 2010 tentang persyaratan kualitas air minum.

Penyediaan air bersih kapal kargo memenuhi syarat kesehatan, dan air bersih yang disuplai dari reservoar Pelindo Manokwari. Beberapa kapal kargo pada saat masuk pelabuhan Manokwari bahkan masih memiliki ketersediaan air bersih yang cukup. Air bersih di kapal memenuhi syarat fisik yaitu, jernih, tidak berasa, tidak berwarna dan tidak berbau (Permenkes RI nomor 416/Menkes/Per/IX/1990). Air bersih yang tedapat pada kapal kargo digunakan untuk kegiatan memasak, mencuci, dan kegiatan di kamar mandi. Saluran tempat pengambilan air dalam kondisi bersih dan tidak terdapat kotoran di sekeliling kran air.

\section{PengelolaanLimbah}

Komponen penilaian pengelolaan limbah di kapal kargo meliputi: air tergenang, limbah cair, limbah padat dan sampah.

Ditinjau dari variabel pengelolaan limbah, terdapat satu kapal (7.69\%) saja yang tidak memenuhi syarat. Kapal tersebut tidak memiliki tempat pembuangan sampah, dan hanya dibuang ditempat sampah yang kondisinya tidak disertai penutup.

Tabel 4. Pengelolaan Limbah Kapal Kargo di Pelabuhan Manokwari

\begin{tabular}{|c|c|c|c|}
\hline No & $\begin{array}{c}\text { Pengolalaan makanan dan } \\
\text { minuman }\end{array}$ & Jumlah & $\begin{array}{c}\text { Persentase } \\
(\%)\end{array}$ \\
\hline \multirow[t]{4}{*}{1} & Air tergenang & & \\
\hline & Memenuhi syarat & 13 & 100 \\
\hline & Tidak Memenuhi Syarat & 0 & 0 \\
\hline & Jumlah & 13 & 100 \\
\hline \multirow[t]{4}{*}{2} & Limbah Cair & & \\
\hline & Memenuhi syarat & 13 & 100 \\
\hline & Tidak Memenuhi Syarat & 0 & 0 \\
\hline & Jumlah & 13 & 100 \\
\hline \multirow[t]{4}{*}{3} & Limbah Padat & & \\
\hline & Memenuhi syarat & 13 & 100 \\
\hline & Tidak Memenuhi Syarat & 0 & 0 \\
\hline & Jumlah & 13 & 100 \\
\hline \multirow[t]{4}{*}{4} & Sampah & & \\
\hline & Memenuhi syarat & 12 & 92.31 \\
\hline & Tidak Memenuhi Syarat & 1 & 7.69 \\
\hline & Jumlah & 13 & 100 \\
\hline
\end{tabular}


Shahraki (2013), menyebutkan bahwa tempat sampah yang tidak dilengkapi dengan tutup akan mengundang kedatangan vektor. Menurut Mutiarani (2017) sampah dibagian dapur hendaknya dimasukkan ke dalam tempat sampah yang dilapisi dengan plastik sampah, tertutup dan kedap air, dipisahkan antara sampah basah dan sampah kering masing-masing mempunyai tempat sendiri. Waktu pengangkutan sampah ke tempat penampungan lainnya supaya diperhatikan jangan sampai berceceran atau menimbulkan bau. Penempatan kantong plastik pada tempat sampah bertujuan untuk mempermudah proses penanganan sampah yang akan diangkut apabila sudah mencapai volume maksimal. Selain itu tempat sampah akan lebih mudah dibersihkan.

Pengelolaan limbah cair pada kapal kargo semua memenuhi syarat kesehatan. Jika ada air tergenang maka akan menyebabkan permasalahan. Air tergenang juga dapat berasal dari deburan air laut dan air hujan yang mengenai geladak kapal (Siregar, 2019). Oleh karena itu, dengan menghilangkan air tergenang dapat mengurangi resiko tempat perkembangbiakan larva nyamuk ataupun seranggalainnya. Pengelolaan limbah padat pada kapal kargo yang diamati dikelola dengan adanya tempat sampah yang layak yaitu kedap air dan tertutup, dan sesuai volume tempat pembuangan dengan limbah yang dihasilkan. Hal serupa dikemukakan Mukaromah dan Lailiyah (2018) bahwa aspek pemeriksaan limbah padat dan limbah medik pada kapal dalam negeri dan luar negeri harus memenuhi persyaratan sarana penampungan limbah pada seluruh kapal.

\section{KESIMPULAN}

Penelitian ini diperoleh bahwa kondisi sanitasi 13 kapal kargo di Pelabuhan Manokwarisecara umum memenuhi syarat sanitasi (91.21\%). Kecuali ada dua komponen yang tidak memenuhi syarat pada variabel ruangan yaitu (a) gudang pada dua kapal $(15,38 \%)$ yang tidak memenuhi syarat dan (b) fasilitas medik, pada enam kapal $(46.15 \%)$. Kapal yang tidak memenuhi syarat, maka direkomendasikan untuk segera memperbaiki hasil temuan pemeriksaan dan akan dilakukan pemeriksaan ulang oleh pihakKKP. Kondisi sanitasi pada variable vector dan binatang pembawa penyakit, variable pengelolaan makanan dan minuman dan variabel pengelolaan limbah pada setiap kapal kargo yang diperiksa, telah memenuhisyarat.

\section{DAFTAR PUSTAKA}

Arikunto, S. 2010. Prosedur Penelitian Suatu Pendekatan Praktik. Rineka Cipta. Jakarta

Departemen Perhubungan RI, 2008. Undang-Undang Nomor 17 tahun 2008 tentang Pelayaran, Jakarta.

Desriyanti .2013. Gambaran Fasilitas Sanitasi di Lingkungan Pelabuhan Sungai Duku Pekanbaru, Jurnal Kesehatan Masyarakat. Universitas Riau.Pekanbaru

Direktorat Jenderal Pencegahan Pengendalian dan Penyehatan Lingkungan. 2009. Standar Operasional Prosedur Nasional Kegiatan Kantor Kesehatan Pelabuhan di Pintu Masuk Negara

International Health Regulation. 2005. Handbook for Inspection of Ships and Issurance of Ship Sanitation Certificates. 1st ed. France: WHOPress

Keputusan Menteri Kesehatan Republik Indonesia Nomor: 425/Menkes/ SK/IV/2007. 2007. Pedoman Teknis Pengendalian Resiko Lingkungan Pelabuhan/Bandara/ Pos Lintas Batas Dalam Rangka Karantina Kesehatan.Jakarta 
Keputusan Menteri Kesehatan Republik Indonesia Nomor: 431/Menkes/ SK/IV/2007. 2007. Pedoman Penyelenggaraan Karantina Kesehatan di Kantor Kesehatan Pelabuhan

Mutiarani, T., Puspita. 2014. Studi Sanitasi Kapal Kargo dan Keberadaan Bakteri E.coli pada Makanan Jadi di Wilayah Pelabuhan Tanjung Perak Surabaya. Tesis. Departemen Kesehatan Lingkungan Fakultas Kesehatan Masyarakat. Universitas Airlangga.Surabaya.

Marpaung, N. D. Nuraini, S, dan I. Marsaulina. 2012. Hygiene Sanitasi Pengolahan dan Pemeriksaan Escherichia Coli dalam Pengolahan Makanan di Instalasi Gizi Rumah Sakit Umum Pusat H. Adam Malik. Jurnal Lingkungan danKesehatan Kerja. Vol. 1 No. 2: Hal.1-10.

Mukaromah, H. dan S Lailiyah. 2018. Higine Sanitasi Kapal dalam Negeri dan Luar Negeri Jurnal Kesehatan Lingkungan 15 (2) :605-614

Putri, A Intan, T. Joko, N. Astorina. 2017. Evaluasi Sanitasi dan Keberadaan Vektor pada Kapal Barang dan Kapal Penumpang di Pelabuhan Tanjung Emas Semarang. Jurnal Kesehatan Masyarakat 5(5) : 356-3346.

Saifullah. 2010. Pengaruh Sanitasi dan Manajemen Kapal Terhadap Kepemilikan Sertifikat Sanitasi Kapal pada Pelabuhan Lhokseumaweh. Tesis. Pascasarjana Universitas Sumatera Utara.

Sofiyan, 2017. Sanitasi Kapal dan Tindakan Sanitasi Anak Buah
Kapal (ABK) mempengaruhi Keberadaan Tikus pada Kapal Kargo di Pelabuhan Tanjung Perak Surabaya. Jurnal Kesehatan Lingkungan 9 (2) : 145-153.

Siregar, Dwi Indri Yani. 2019. Tinjauan Higiene Sanitasi Kapal Kargo di Pelabuhan Belawan Wialyah Kerja Kantor Kesehatan Pelabuhan (KKP) Kelas I Medan. Karya Tulis Ilmiah. Politeknik Kesehatan Kemenkes Medan Jurusan Kesehatan Lingkungan. Medan

Sumantri, A. 2010. Kesehatan Lingkungan \& PerspektifI slam. Jakarta: Prenada Media

Suryani, D. A Hendrawan. 2020. Studi tentang Sanitasi Kapal. Jurnal Saintara 4 (2)

Shahraki, G. 2013. Evaluation of Sanitation in an IPM Program for Cocroach Infestation in Housing. Yasuj University of Medical Sciences.

World Health Organization.2007. International Health Regulation Gaide to Ship Sanitation. Geneva.

World Health Organization. 2005. International Health Regulation tahun 2005. Jakarta.

World Health Organization. 2005. Medical Guide for Ship. Edisi ke II, Switzerland.

Yunus, S. JM L, Umboh dan O Pinontoan. 2015. Hubungan Personal Hygiene danFasilitas Sanitasi dengan Kontaminasi Escherichia coli Pada Makanan di Rumah Makan Padang Kota Manado Dan Kota Bitung. Jurnal Ilmu Kesehatan Masyarakat Universitas Sam Ratulangi 5(3) 